Notre Dame Law School

NDLScholarship

Journal Articles

Publications

2009

\title{
Does Free Exercise of Religion Deserve Constitutional Mention?
}

John M. Finnis

Notre Dame Law School, john.m.finnis.1@nd.edu

Follow this and additional works at: https://scholarship.law.nd.edu/law_faculty_scholarship

Part of the Constitutional Law Commons, Natural Law Commons, and the Religion Law Commons

\section{Recommended Citation}

John M. Finnis, Does Free Exercise of Religion Deserve Constitutional Mention?, 54 Am. J. Juris. 41 (2009).

Available at: https://scholarship.law.nd.edu/law_faculty_scholarship/863

This Lecture is brought to you for free and open access by the Publications at NDLScholarship. It has been accepted for inclusion in Journal Articles by an authorized administrator of NDLScholarship. For more information, please contact lawdr@nd.edu. 


\title{
DOES FREE EXERCISE OF RELIGION DESERVE CONSTITUTIONAL MENTION?
}

\author{
JOHN FINNIS
}

John Dewey was born in 1859 , the year that saw the publication-celebrated worldwide this 150th anniversary - of Charles Darwin's The Origin of Species. I value the opportunity to address you today ${ }^{1}$ under the distinguished auspices of Dewey, though it is Darwin, I shall argue, who is the better guide when we try to think about the place of religion in a society that aspires to be fair and sustainable. The question whether such a society would include the free exercise of religion among its constitutional guarantees has recently become a focus of debate amongst legal philosophers. The philosophy of law-the frame for this series of endowed lectures--is in some ways the most humble, low-level of philosophy's branches. But that same lowliness entails that one cannot do legal philosophy well without investigating and taking positions in all the higher levels and domains of practical philosophy, not to mention the epistemology and metaphysics which practical philosophy partly presupposes and partly informs. So legal philosophy is like law and lawyering: a place where all the great questions come to a head and become truly practical-a place proximate to decisions and actions affecting real persons and their lives and fortunes, decisions and actions whose rational soundness will depend on access - through culture, insight, or philosophy - to the deepest principles of morality and most strategic truths about human beings and their environment. So: a privileged place to work in.

In the debate I mentioned, some contemporary American legal and constitutional theorists hold that there is nothing about religion or its free exercise that calls for particular respect, or any mention in constitutional bills of rights. That is the thesis which my lecture concerns. Religion, these theorists hold, has no such dignity, though (they add) history's testimony to the vulnerability of religions or their adherents, especially their vulnerability to oppression by other faiths, helps explain and in a weak sense justify the First Amendment's denial of Congressional power to make law either "respecting an establishment of religion" or "prohibiting the free thereof." Ronald Dworkin is a principal proponent of the thesis, ${ }^{2}$ but its most energetic

1. This paper was first delivered as the annual John Dewey Lecture at the University of Minnesota Law School in March 2009.

2. Ronald Dworkin, Justice in Robes (Cambridge, MA: Harvard University Press, 2006), 
exponents over the past fifteen years have been Christopher Eisgruber and Lawrence Sager, whose joint work culminates in their book Religious Freedom and the Constitution. ${ }^{3}$ The book argues for a principle they call "Equal Liberty," a principle which is demanded by fairness in religiously diverse societies and which "denies that religion is a ... category of human experience that demands special benefits and/or necessitates special restrictions," or any "special immunity for religiously motivated conduct."

In Eisgruber and Sager's theory or principle of the "Equal Liberty" there is much that may seem welcome. They argue strenuously against the metaphor of "separation of Church and State," and their theory equally discredits not only that slogan but also the once prevailing Supreme Court interpretation of "no establishment of religion" that forbad any state aid to religious or religiously affiliated enterprises. They offer to defend, not a secularism that would reject, exclude or disparage religion, but what they see as the healthy secularity of non-religious institutions-say, secular public schools - which while declining to be (and prohibited from being) "overtly or specifically religious," "aspire to constitute a practical realm in which various competing ... philosophical and religious views may coexist and constructively interact." They have no time for Rawlsian proposals to expel from the public domain all religious arguments or grounds for decision-making; ${ }^{8}$ they share, I think, Dworkin's (and Joseph Raz's) healthy scepticism about that ramshackle Rawlsian project-he calls it "political liberalism"- - which in all really important decisions about human rights and the common good would banish concern for truth and in its place put an imaginary overlapping consensus of the "reasonable" views of all "reasonable" people (views supposedly identifiable as reasonable without reflection on their truth). They hold-rightly, I think - that in these matters neutrality is not an option. As to free exercise of religion, Eisgruber and Sager support the approach in Employment Division v. Smith," the Peyote case, upholding "neutral and generally applicable" laws even when they happen to restrict some religious practice and no "compelling state interest" required them to do so. That

134; Dworkin, Is Democracy Possible Here? Principles for a New Political Debate (Princeton, NJ: Princeton University Press, 2006), 60-62.

3. Christopher Eisgruber and Lawrence Sager, Religious Freedom and the Constitution (Cambridge, MA: Harvard University Press), 2007.

4. Ibid., 6.

5. Ibid., 13.

6. Ibid., 313.

7. Ibid., 216 (emphasis added).

8. See ibid., 48-50 (not explicitly mentioning Rawls's "political liberalism")

9. 494 U.S. 872, 890 (1990), Scalia, J. for the Court. 
approach is much less welcome to many who recognize the particular good of religion and religious liberty, but when I revisit it later in this lecture I will not be arguing against it. Yet for all this, the over-arching theory of Equal Liberty proposed by Eisgruber and Sager is, I think, radically unsound, at the very least insofar as it denies to religion and religious liberty any moral or constitutional status distinct from other "deep commitments."

Their theory's first exposition was entitled "The Vulnerability of Consciences: The Constitutional Basis for Protecting Religious Conduct."10 But the title can give a mistaken impression of their central thesis. For they deny that conscience as the rational faculty of practical judgment has any more claim than religion to constitutional privilege or even protection. " Rather, the proper object of constitutional protection is any "deep concern," any and all "deeply" motivated and self-shaping attitudes and behavior. Whether or not these are religious or even conscientious, all alike are entitled to "equal regard." There is, they say, a "grand diversity of relationships, affiliations, activities, and passions that share a constitutional presumption of legitimacy" because in them members of "a modern, pluralistic society...find their identities, shape their values, and live the most valuable moments of their lives." 12 Religious acts, they concede, have the same dignity and constitutional status as the "relationships, affiliations, activities and passions" under discussion. Their article did not say how far this wider category extends, and their book, too, is not much concerned to clarify the matter. But it does make clear that, in their view, the freedom of a religious association such as the Catholic Church to maintain a male priesthood is defensible only as an instance of the constitutional principle that "there are a variety of personal relationships in which members of our political community are free to choose their partners [as in Lawrence $v$. Texas], associates or colleagues without interference from the state." ${ }^{13}$ And their 1994 article had several times explicated the phrase "deep concern(s)" (which in the book is usually rendered "deep commitment(s)") as including "passionate" acts and relationships. ${ }^{14}$

10. University of Chicago Law Review 61 (1994): 1245-1315.

11. Ibid., 1263, 1268-70.

12. Ibid., 1266. In truth, identities are shaped, not merely found, and values are found (or imagined) not merely shaped.

13. Religious Freedom and the Constitution, 65; Lawrence v Texas, 539 U.S. 558 (2003), involving partnership in casual homosexual sodomy, is cited on the preceding page.

14. "The Vulnerability of Consciences," 1283 . At the very outset (1245n), the authors say that "an important theme of this essay is that religion does not exhaust the commitments and passions that move human beings in deep and valuable ways." 
Eisgruber and Sager are right to hold that religion, if it is (as they think) just one among the deep passions and commitments that move people, does not deserve constitutional mention on account of any special dignity or value. True, this hypothesis does not warrant their conclusion that mention of religion in constitutions is defensible — if at all—only because religious people (the authors always seem to assume religious majorities) have been so beastly to each other (they assume, to minority religions) so often that historical constitution-makers could reasonably treat the exercise of religion as needing protection just because specially vulnerable to religiously motivated discrimination. For the argument forgets the threat to religious practice that can come from atheist or other secularist hostility to religion. But much more important is the hypothesis itself: that religion is just one deep and passionate commitment amongst others. This is lethal to religion, and I want to try to show why.

Before setting out my positive argumentation, I think it is fair to remark that theirs is a thoroughly external view. ${ }^{15}$ They treat religion in the way that Ronald Dworkin regularly treats views of legislators or "majorities" with which he is unsympathetic, that is, not as propositions about rights or common good, or as any other proposition or premise arguably justifying a normative conclusion, but instead as mere expressions of distaste or disapproval, accompanied by an appeal to the power of those who hold these views-their power as a majority to give effect to their attitude, their passionate commitment. ${ }^{16}$ Eisgruber and Sager fall into this Dworkinian sort of sophism in their book's last pages, where they reductively treat the concern of religiously minded people that America acknowledge its dependence on God as a mere concern for "their [own] wellbeing," a mere complaint that "they [the religiously minded] are being deprived of an environment" that they value. ${ }^{17}$ The externality of Eisgruber and Sager's view of religion-their treating religious propositions as propositions inherently incapable of conveying any understanding of, or rational response to, any feature of reality,

15. In Religious Freedom \& the Constitution, 103, they explicitly speak from, or on behalf of, “an external, secular perspective."

16. I first pointed to this sophistic technique of Dworkin in "A Bill of Rights for Britain?" Proceedings of the British Academy 52 (1986): 303-331 at 309-311, and again, with reference to its pernicious echoes in recent Supreme Court doctrine, in "Universality, Personal and Social Identity, and Law," (Third) Congresso Sul-Americano de Filosofia do Direito and (Sixth) Colóquio Sul-Americano de Realismo Jurídico, Porto Alegre, Brazil, 4 Oct 2007 (http://papers.ssrn.com/sol3/papers.cfm?abstract_id=1094277). See also Finnis, "H.L.A. Hart: A Twentieth-Century Oxford Political Philosopher, American Journal of Jurisprudence 54 (2009): 161-85 text at nn.55-57.

17. Religious Freedom and the Constitution, 284-5. 
and their failure even to contemplate a line of rational inquiry, reflection and judgment such as might lead people to affirm the existence of a transcendent intelligent and provident creator-is an externality further manifested in their repeated remarks about "intelligent design." For in these remarks they go beyond the rational (albeit not wholly compelling) objection that gaps in experimental science call for more experimental science to two additional claims: (1) that the "suggestion" that there exists an intelligent designer is merely "a vague kind of religious view," that is to say a mere "hypothesis grounded in religion"; and (2) that any identification of the designer as God rather than gods, wizards, fairies, or "transcendental pasta" (their scornful phrase), is a mere profession of religious faith. ${ }^{18}$ Assessing these two claims will get us closer-indeed close - to the root of this lecture's title question.

II

Is the "suggestion" that there exists a transcendent intelligent designer a "hypothesis grounded in religion"? At the age of 65 , seventeen years after the publication of The Origin of Species and six years before his death, Darwin wrote an Autobiography, which he revisited occasionally to supplement. It was a little too candid, intellectually, for some in his family; so the posthumous first publication of it in 1882 was not quite complete; but the deletions were eventually restored. In a short paragraph, present in his first draft and never revised, he speaks of a "source of conviction in the existence of God," a source which is "connected with the reason and not with the feelings" and therefore "impresses me [him] as having much more weight" than another source that he had mentioned, namely, "the sense of sublimity," or more exactly the sort of "higher feelings of wonder, admiration and devotion" that, as he had years before recorded in his journal, filled and elevated his mind whilst standing in the midst of the grandeur of a Brazilian forest. By now, in 1876, even "the grandest scenes would not cause any such convictions and feelings to rise in my [his] mind." But when he sets feelings and lack of feelings to one side, and attends instead to reason, that is to thinking about data and their explanation, then once again there arises a "conviction in the existence of God" which

follows from the extreme difficulty or rather impossibility of conceiving this immense and wonderful universe, including man with his capacity of looking far backwards and far into futurity, as the result of blind chance or necessity. When thus reflecting I feel compelled to look to a First Cause having an intelligent

18. Ibid., $190,281,310$ at n. 56 . 
mind in some degree analogous to that of man; and I deserve to be called a Theist. ${ }^{19}$

Now it is clear that Darwin, when he wrote this, had for some years had no religious faith, no religion, no desire to adjust his living and thinking, in any way, to respond in any way to the intelligent mind of any supposed First Cause. Doubts about whether the human mind can be trusted when "it draws such grand conclusions," and about whether the felt, or rather adjudged, necessity of "the connection between cause and effect" instead "depends merely on inherited experience," had reinforced the source of doubt that earlier led him to abandon Christian faith, namely, the suffering and death of his own daughter and, beyond that, the spectacle of all the suffering and waste in the world of nature. So he concludes: "The mystery of the beginning of all things is insoluble by us; and I for one must be content to remain an Agnostic."

The structure and sequence of Darwin's inner debate-as traced in this autobiographical reflection on the cause of the world and of its evolution-are philosophically sounder than the debate's conclusion. His foundational judgment (when really thinking, not feeling) was: it is impossible rationally to ascribe the universe to chance or "blind necessity," and necessary to ascribe it instead to an intelligence which is neither a part of nor the totality of the universe but nonetheless the universe's cause. That foundational judgment is reasonable, sound and indeed inevitable, provided we correctly understand his phrase "impossible to conceive," and that phrase's implicit counterpart or entailment "necessary [compelled to conceive]" and, for that matter, my term "inevitable." Correctly understanding these key terms requires more precision than, I think, Darwin himself achieved. The impossibility in question is not the impossibility of the logically contradictory or incoherent, and the implicit necessity is not logical necessity or strict entailment. Nor is it a matter of "psychological necessity," or again of that necessity-of-habit which Darwin, an avid amateur of David Hume, perhaps has in mind when he speaks of "inherited experience;" and equally it would be gratuitous to appeal here, in a Kantian manner, to a "structure" of the human mind. The necessity is, rather, the rational necessity of adhering to those norms of rational enquiry

19. The Autobiography of Charles Darwin 1809-1882: with original omissions restored, ed. Nora Barlow (London: Collins, 1958), 92 (emphasis added). Some time after writing this, Darwin inserted, immediately after this passage: "This conclusion was strong in my mind about the time, as far as I can remember, when I wrote the Origin of Species; and it is since that time that it has very gradually with many fluctuations become weaker." 
and judgment which articulate what experience of discovering reality shows is needed for overcoming ignorance, illusion, and error. ${ }^{20}$

Such norms guide all scientific inquiry, all scientific discovery and all scientific achievements and applications - and are the source, equally, of all enquiry, discovery and judgment in fields which lie wholly or partly beyond the methods of natural science, fields such as mathematics, logic, philosophy, history, and the interpretation of texts and conversations. In all these fields, truth is found and knowledge of reality is won by hypothesizing (and then, when evidence and argument fail to disconfirm it, appropriately concluding to) some explanation, some explanatory factor or state of affairs or reality-what Darwin reasonably calls some cause--in preference to mere chance or inexplicable ("blind") necessity. So, one of the many rationality norms is: an adequate explanatory reason why something is so rather than otherwise is to be expected, unless one has a reason not to expect such an explanatory reason. Chance, of course, there is aplenty in a world where events and processes, each of which has its own intelligible explanation(s), coincide. But science progresses constantly by treating chance as the residuum of coincidence in a domain dominated by what is explicable because it is not by chance. (So Richard Dawkins's celebration, earlier this anniversary year, of Darwin and Darwinism ends by indignantly repudiating the thought that evolution proceeds or has ever proceeded by chance! $)^{21}$ Absolutely no entity, process or other state of affairs in the world we can in any way experience or know shows any sign of necessarily-or, for that matter, causelessly - being what it is; or any sign of either necessarily or causelessly being actual rather than non-existent, or necessarily or causelessly doing what it does or changing as it does. Postulating that the whole (the universe or cosmos or universe of universes) has existed for an infinite time-a postulate that philosophers like Moses Maimonides and Thomas Aquinas are happy, indeed keen, to entertain ${ }^{22}$-does not make it reasonable to predicate of the whole either a necessity or a causelessness that is discoverable in none of its component entities or state of affairs. Far more reasonable is it to infer that the actuality and intelligibility of every entity, process or state of affairs result from a sui generis reality which has what it takes both to exist-be actual-without being caused and to cause, intelligently, absolutely every such resultant ("created") entity, process and

20. See Finnis, Natural Law and Natural Rights (Oxford: Clarendon Press, 1980) [NLNR], 68-9, 385.

21. Richard Dawkins, "Darwin, the Truth," Times Literary Supplement, February 4, 2009.

22. See Finnis, Aquinas: Moral, Political and Legal Theory (Oxford and New York: Oxford University Press, 1998), 301, citing Summa Theologiae, I q. 46, a. 2; Summa contra Gentiles, II c. 38 n. 8; and three other texts. 
state of affairs. ${ }^{23}$ (Nor is it difficult to show that no set of gods, no wizard or fairy, and no transcendental pasta, could have what it takes to be sheer actuality, without trace of mere potentiality, the pure actuality needed to explain a universe in constant development from potentiality to actuality.)

If one does what Darwin, it seems, did not sufficiently do, and takes fully into account (i) the wholly sui generis character of this transcendent actuality and causality of everything else, and (ii) the accordingly quite sui generis character of what he like Aquinas called the analogy between the Creator's and our creaturely minds, then one will discern the proper response to the doubts which in Darwin's mind somehow seemed to make possible what he had rationally judged impossible, namely conceiving of this world as existing without an intelligent First - or better, transcendent, sui generis - Cause. For beyond (or behind) the doubt which arbitrarily reduced the rational demand for an explanation to mere habit, and the doubt which a priori declared untrustworthy the only available explanation, there lay the doubt-which is not arbitrary or a priori-that a transcendent intelligence would not have chosen to make this world with its apparent "waste" and its all too real not apparent suffering. The proper response to this doubt looks to the very consideration which Darwin treated as ground for abdicating from the whole enquiry and for accepting, agnostically, the equal possibility of what he had already judged impossible-the non-existence of an intelligent and transcendent cause. What consideration was that? Darwin put it in various similes and metaphors, all acknowledging or asserting the inadequacy of our grasp of the relevant realities and possibilities involved in conceiving of a transcendent and ultimate explanation of everything (including, of course, of the domains of mathematics and logic, or knowledge of the past, of intending and understanding intentions, and of mind's effortless though not unconditioned mastery over matter, as in speaking, or pointing). As I summed up Aquinas's fundamental response to the "problem of evil":

Straining to ascribe everything to chance rather than a creative intelligence, materialists object that in some respects the pattern and evolution of things is wasteful, pointless, badly ordered, unintelligent. They do not attend to the fact that much which seems to them pointless or wasteful is still somehow a describable and to that extent stable and intelligible pattern. And in judging it

23. Anthony Flew, There is a God: How the world's most notorious atheist changed his mind (New York: Harper, 2007), 74-158, surveys the state of the debate, with particular focus on argumentation (e.g., of scientists like Einstein, Heisenberg, Planck and others) analogous to Darwin's, argumentation whose strictly philosophical respectability Flew briefly vindicates. For a more fundamental treatment of philosophical issues about the existence of God, see Germain Grisez, God? Philosophical Preface to Faith (South Bend, IN: St Augustine's Press, 2004), cited under the first edition's title in $N L N R$, ch. xiii. 
defective or unintelligent because they do not understand its point, they resemble a country bumpkin (rusticus; idiota; ignorans) who, from the true premise that he does not understand what is going on in a busy laboratory or hospital theatre, draws the conclusion that what is going on is random, unintelligible, pointless, or foolish, or perhaps just needlessly complex. ${ }^{24}$ The intention of an intelligence capable of projecting and actualising the entire cosmos and all its interlocking orders vast and miniscule (including human minds with all their capacities to understand and reason logically, mathematically, and interpretatively) is not an intention we could ever reasonably hope to understand fully by reasoning from those truths about it which, in our fruitful but laborious inferences from experience, we do manage to understand. ${ }^{25}$

Or again, as I concluded a discussion of evil and creation in my Natural Law and Natural Rights,

The norms in terms of which we judge states of affairs to be evil, in any of the four orders [of human knowledge: nature, logic, morality and technologies], are not applicable to $\mathrm{D}$ [the transcendent first cause] as creator. Thus we have no ground to judge that D's creative causality is defective. ${ }^{26}$

Let me pause to take stock. I asked: Is the "suggestion" that there exists an intelligent designer a "hypothesis grounded in religion"? The example of Darwin shows well enough why it is not. The lines of thought that converge on the conclusion that one should affirm a transcendent cause are lines of thought continuous with all our enquiries, reflections and judgments in every field of science and rational discourse. They are philosophical, though in substance accessible to informal "common-sense" reflection. They are the perennial root and cause, rather than a consequence, of religious belief. Indeed, in themselves they are not yet religious at all. Before we can speak of religion, we must add further affirmations, including at least one further philosophical affirmation, and also some affirmations within practical philosophy (ethics) and some response(s) of freely willing relating of oneself to the divine. These points merit some expansion.

24. See Aquinas, Collationes Credo in Deum 1; Summa contra Gentiles I c. 3 n. 4; Scriptum super Libros Sententiarum Petri Lombardi [Sent.] I d. 39 q. 2 a. 2 ad 5; De Veritate q. 5 a. 5 ad 6; also Summa Theologiae I q. 116 a. 1c and Summa contra Gentiles III c. 92 n. 12 [2678] (gravediggers who are not aware of their director's purpose of finding buried treasure in the graveyard). The flourishing of evildoers and the miseries of decent people in this world (see I Sent. d. 39 q. 2 a. 2 obj. 5; Expositio super Iob prol.) are in accordance with the abyss of the incomprehensible judgments of God \{secundum altitudinem incomprehensibilium iudicium Dei\}: Quaestiones de Quodlibet III q. 3 a. 3c; also I Sent. d. 39 q. 2 a. 2 ad 5.

25. Finnis, Aquinas, 304.

26. NLNR, 391. 
III

The philosophical character of the arguments for and affirmation of God's existence is strongly suggested by the philosophical lengths to which thinkers tend to go who make it their business to reject that argumentation and affirmation. David Hume denies the reality of human insight and equally the reality of natural causation, trying in vain to replace the one with habitual conjunctions of images (misnamed by him "ideas") and the other with mere correlation or repeated coincidence. Richard Dawkins's disproof of God, in his The GodDelusion, ${ }^{27}$ uncritically assumes, explicitly, that complex realities can only be caused by more complex realities-implicitly, that mind is no more than complexified matter - an assumption falsified by every move one makes, in thought, to clarify one's statements and avoid fallacious arguments, and indeed by every meaning-conveying word we utter, and every project one brings to fruition. John Dewey made even wider and higher the protective rampart against enquiries that reach out for ultimate explanations; he rejected as superseded the "notion" that "knowledge is a disclosure of reality, of reality prior to and independent of knowing" and the "notion" that "knowing is independent of a purpose to control the quality of experienced objects." 28 The latter position of his was an instrumentalist pragmatism (significantly coarse compared with the philosophy articulated by pragmatism's founder Charles Peirce) which harmonized with Dewey's denial, in his legal philosophy, that there are any principles which are more than "working hypotheses, needing to be constantly tested by the way in which they work out in application to concrete situations"- a denial which rendered merely provisional, indeed unintelligible, various unalienable human rights which have had to be insisted upon in the aftermath of Nazism and the like. ${ }^{29}$ And Darwin like any other serious scientist could scarcely have assented either to Dewey's denial that knowledge discloses reality or his assertion that knowledge is all for the sake of controlling experience-positions each of which cuts off both the sense of wonder that is the motor of science and blocks the search for a knowledge of the past (not least the past of evolution).

27. Richard Dawkins, The God Delusion (London: Bantam Books, 2006).

28. John Dewey, The Quest for Certainty: A Study of the Relation of Knowledge and Action (New York: Minton, Balch, 1929), 43-4.

29. The impact of Dewey's position can be measured by Posner's statement in Law, Pragmatism, and Democracy (Cambridge, MA: Harvard University Press, 2003): 'Not...that the judge has a duty to abide by constitutional or statutory text, or by precedent. That would be the idea rejected by John Dewey that law is entirely a matter of applying rules laid down by the past." 
But now it is time to make the other point: the judgment that God exists as explanation or causal source of everything's actuality, existence and intelligibility is no mere contemplation of the past. It includes or at least entails a judgment (indeed several judgments) about the relation between our own thought and action and the ongoing causal activity of the transcendent creator, the activity traditionally called divine providence. For first, since every entity, process or state of affairs somehow caused by the transcendent source is contingent, not necessary, it is reasonable to think of divine causation as not only intelligent but also free-as if it were causing through free choice: to create something rather than nothing, and this totality rather than other possible universes. And secondly, it is clear to us that our own activity, including our own thinking things through, is dependent, for its happening and achieving anything at all, on the cooperation of providence. Both these inferences are still philosophical-thoughts we have no need or sufficient reason to call religious. We start to move into the zone of the religious only with a third line of thought about the relation between our activity and divine providence.

And that is this. The world we find and do not make includes not only the normativity or directiveness of logic, but also the normativity of basic practical principles such as those that pick out knowledge and truth as an intelligible good to be preferred to ignorance and muddle, or again pick out harmony with other persons as another such good, to be preferred to hatred and war; and so forth. For both these reasons, it is reasonable to think of the creator - the transcendent, intelligent and freely choosing source of reality and meaning, and of intelligible goods and our directedness towards them-as being somehow personal, and as personally, so to speak, anticipating human fulfilment and leading us, via our own understanding, deliberation and free choices, towards such possible fulfilment. ${ }^{30}$ To have thought so far, something which takes time to spell out as I have but which common sense grasps as quick as thought, is to have reached the very threshold of a new, equally effortless, but now fully practical insight: that it would be good to be responsive to and-in hope, because in awe of one's finiteness and dependence - cooperative with this transcendent personal source of whatever good we any of us could achieve. That is the good whose pursuit is religion and its exercise.

30. Germain Grisez, Joseph Boyle and John Finnis, "Practical Principles, Moral Truth, and Ultimate Ends," American Journal of Jurisprudence 32 (1987): 99-151 at 279-80. Nor is this line of thought foreign to pre-Christian philosophy, as is demonstrated by Plato's reflections on the moral and political importance of (acknowledging clearly) divine concern for human life and choices: see Finnis, "On the Practical Meaning of Secularism," Notre Dame Law Review 73 (1998): 491-515. 
To be more precise, it is, so far forth, the good of natural religion, of an understanding of providence, dependence, and co-operation which does not yet include (though it would reasonably be open to) the belief, the faith, that it has been informed by some inter-personal communication, private or public, from-some revelation of-the transcendent and divine. ${ }^{31}$ It is an understanding that understands itself still to be from end to end a series of rational inferences from experience, natural science, and philosophical reflection. This remains so, even when the interpretation of divine providence's governing of events is adventurously confident, as for instance in a passage near the beginning of the very first presidential inaugural address, exactly 220 years ago next month. (You should have in your mind's eye the President, not as the stiff, florid figure of later portraits, but as the intense, farseeing man sculpted two years earlier, with admiration and genius, from a lifemask, by a fellow freemason, Jean-Antoine Houdon, who took the better version back with him to France.) Having begun by recounting the anxious process of deliberation and discernment by which he decided to accept his country's summons out of longed-for retirement, Washington observes that-

it would be peculiarly improper to omit in this first official Act my fervent supplications to that Almighty Being who rules over the Universe, who presides in the Councils of Nations, and whose providential aids can supply every human defect, that his benediction may consecrate to the liberties and happiness of the People of the United States a Government instituted by themselves for these essential purposes: and may enable every instrument [official or other public servant] employed in its administration to execute with success the functions allotted to his charge. In tendering this homage to the Great Author of every public and private good I assure myself that it expresses your sentiments not less than my own; nor those of my fellow-citizens at large less than either. No People can be bound to acknowledge and adore the invisible hand which conducts the Affairs of men more than the People of the United States. Every step, by which they have advanced to the character of an independent nation seems to have been distinguished by some token of providential agency. ${ }^{32}$

31. On the importance of natural religion, and the idea of natural religion, in the thought of the founders of the American republic, see Gerard V. Bradley, Religious Liberty in the American Republic (Washington, DC: Heritage Foundation, 2008), 8-9, 29, 40-41, 46 and 1-46 passim. The report of the U.S. Senate Committee on the Judiciary on petitions to abolish the office of chaplain, 21 January 1853, lucidly affirms that "our fathers...did not intend to send our armies and navies forth to do battle for the country without any national recognition of that God on whom success or failure depends..."

32. The Papers of George Washington, ed. W.W. Abbot et al., Presidential Series, vol. 2, ed. Dorothy Twohig (Charlottesville, VA: University Press of Virginia, 1987), 174. 
Those steps, you all recall, included for Major General Washington and his forces many defeats, retreats, disasters, along with many and eventually decisive victories, and then the peace settlements, confederation and the making and adopting of the Constitution itself.

The natural, philosophical religion invoked by President Washington is articulated with maximum economy in the prayer (the Regents' prayer) that in 1962 was expelled from the public schools of New York by the Supreme Court in Engel v Vitale 33 : "Almighty God we acknowledge our dependence upon Thee, and we beg Thy blessings upon us, our parents, our teachers and our Country." Such is the core both of natural religion, and of any paradigmatic form of religion that goes beyond philosophy and natural religion to elaborate a doctrine and worship informed or mandated by some kind of non-philosophical communication from or with the divine reality-a form of religion such as one finds richly elaborated in, say, Judaism or Orthodox or Catholic Christianity. (There are, of course, non-paradigmatic instances of religion, some of them historically highly significant such as Buddhism, in which the relation between the transcendent and the world is differently conceived.) The human good of religion is centrally the good of being aligned in one's intelligence, will, and freedom with the intelligence, will, and freedom of the Creator; notions such as fall, repentance, forgiveness, redemption all fall within the ambit of that generic alignment, that assimilatio and adhaesio, as Aquinas puts it, an alignment that even natural religion can at least envisage and esteem even when, like Aristotle, it responsibly judges that the divine is too transcendent for us to hope for a relationship such as friendship. ${ }^{34}$ One does not get the measure of even merely natural religion's dignity and value if one remains with the conception of religion's value that Andrew Koppelman has proposed on the basis, not least, of the "place-holder" sketch of a good of religion that I offered in chapter IV of Natural Law and Natural Rights. ${ }^{35}$ Koppelman's intentions in this enterprise are good - he is a critic of Eisgruber and Sager's unadmitted secularism - but the content and dignity of the good of religion cannot be identified (as he attempts to identify them) with a mere human questing, considered without regard to the reasons that point both to the existence of God as proper and real object of such questing, and to something of the divine nature and activity.

Nor should we neglect the importance of natural religion's underpinning of the idea, the truth, of human equality, the equality of the one species of animal

33. 370 U.S. 421 (1962).

34. Nicomachean Ethics VIII.7: 1158b35, 1159a4; see NLNR, 397.

35. See Andrew Koppelman, "Secular Purpose," Virginia Law Review 88 (2002): 87 at 130-31; "Is it Fair to Give Religion Special Treatment?" University of Illinois Law Review (2006): 571-603 at 593-4. 
whose members, each and all unlike (as far as we can tell) all other animals, have the radical capacities of persons. Those capacities are to participate in the immaterial life of the spirit, the life of meanings, logic, truths and errors (known by their consistency with evidence and principle, not by their correlation with any brain-state), about the past, the actual, and the possible. As one of the sub-clauses ${ }^{36}$ in the Indian Constitution's clause on religious liberty reminds us, it is possible for a developed religion to distort natural religion's awareness of human equality under the supreme, creative spiritual reality. But a deeper threat to human equality is materialist, scientistic denials of spirit, denials which strip away the one aspect of human reality that makes us equals in dignity despite the manifold inequalities between us. It seems significant that those who expend the patrimony of a religious, anti-materialist civilization, the patrimony we call rights, by extending rights to sub-personal animals, are characteristically to be found denying the equal rights of young or disabled human persons. Prayer like the New York Regents' prayer, acknowledging to God our dependence and addressing to the unseen God, by thought, a petition, both presupposes and reinforces the anti-materialist truth so essential to the validation of human rights.

\section{IV}

Eisgruber and Sager admit that the rule in Engel $v$. Vitale, expelling all such prayer from public schools even when opting-out is fully permitted and protected, cannot be adequately justified by simple appeal to the risk of coercion by social pressure. That sort of argument, they concede, certainly could not justify such progeny of Engel as Santa Fe Independent School District $v . D o e^{37}$ : after all, anyone can stay away from a football game at which there will be school-sponsored prayer. They accept that these judicial prohibitions, picking out the exercise of religion for seemingly "unique prohibitions that have no secular analogues," 38 seem on their face incompatible with Equal Liberty. But Eisgruber and Sager vigorously defend the absoluteness of the rule in these cases. They do so by appealing to a wideranging principle of disparagement:

Government-sponsored prayer rituals involve a public embrace of the faithful...more precisely, of those whose faiths are consistent with mainstream

36. Art 25(2)(b): “[The state may make law] providing for social welfare and reform or the throwing open of Hindu religious institutions of a public character to all classes and sections of Hindus."

37. 530 U.S. 290 (2000).

38. Religious Freedom and the Constitution, 161. 
public prayer. As a result, their social meaning includes this blunt message: The real members of this community (the school community and by extension the larger community serviced by the school or school district) are practicing Christians of a certain sort; others dwell among us but lack the status of full membership. The public rituals create a class of outsiders and thereby disparage those relegated to that status. ...Proponents... will no doubt object that neither they nor school authorities have any intention to disparage anybody; their goal is simply to make prayer rituals available to those who will appreciate them....[But] the relevant question is not about the intentions of particular speakers, nor about the perceptions of particular audiences, but rather about the social meanings of rituals, practices, and religions. ${ }^{39}$

You are entitled to be puzzled by a "meaning" which floats free both of the intentions of the speaker or acting person and of the perceptions of the audience. But this argument from unintended but supposedly real disparagement is now a mighty force in constitutional and political arguments against not only religion or religions but also against the institution of marriage, the primacy of our language within our own country, and every other aspect of our culture which is not universally shared and about which some people, whether or not part of our community by birth, are discontented. To require immigrants to speak our language, argues Joseph Raz, is to disrespect them, to express a judgment that their culture is inferior and to be eliminated. ${ }^{40}$ Here Raz, for so many years a stern critic of Ronald Dworkin, implicitly throws in his lot with Dworkin's long-running sequence of arguments, each one springing up when its predecessor twin or cousin was refuted, all revolving around the claim that some state action manifests disrespect, or lack of equal respect, for those persons whose conduct it restricts or otherwise affects - restricts or affects perhaps, in truth, out of lively concern to protect them from their own folly or weakness.

To all these attributions of disrespect, insult, or disparagement, unhinged from any intent, we should reply that they are gratuitous and groundless, essentially sophistic fictions. The meaning of the resolve to pray together is simply not that those who abstain or absent themselves are not full members of the community. They are full members of the community, with every single right that everyone else in it enjoys, and every single right enjoyed by those who engage in the corporate activity from which they are entitled to dissent, and with whom they have, pace Eisgruber and Sager, equal

39. Ibid., 163-4 (bold type added).

40. Joseph Raz, "Multiculturalism," Ratio Juris 11 (1998): 193-205 at 200, referring also to Raz, Ethics in the Public Domain, 2d ed. (Oxford: Oxford University Press, 1995), 178. On all this see my "Universality, Personal and Social Identity, and Law," part III. 
constitutional stature. ${ }^{41}$ Similarly, those countries or legislatures or citizens who insist that immigrants learn the country's language, lest a Balkanized country be bad for all alike, need neither have nor convey any view that the immigrant culture is inferior, or any intent to eliminate or in any way disparage it. And in those cases where they do judge some cultural syndrome inferior, and hope or even plan for its elimination, their judgment need be no more unfairly disrespectful of persons than the judgment that sexual relations between grown men and ten-year old girls are immoral, harmful, and, however revered the men who have indulged in them, are (like female genital mutilation) to be eliminated from our community.

Time to take stock again. I have assembled the main premises for a primary answer to my title-question. Religion deserves constitutional mention, not because it is a passionate or deep commitment, but because it is the practical expression of, or response to, truths about human society, about the persons who are a political community's members, and about the world in which any such community must take its place and find its ways and means. Even the many seriously misguided religions tell in some respects more truth about the constitution's ultimate natural (transcendent, supra-natural) foundations than any atheism or robust agnosticism can.

This thesis is consistent with the kind of argument I develop in all chapters save the last in my Natural Law and Natural Rights and Fundamentals of Ethics-the argument that practical reason's first principles can be understood and acknowledged, and their normative implications extensively unfolded into rich, substantive moral, political and legal theory, without relying upon, presupposing, or even adverting to, the existence of God or providential order. But: if it is true, as I argue in the final chapter of each of those books, and of my Aquinas book, and have outlined again today, that the rationality norms which guide us in all our fruitful thinking also, and integrally, summon us to affirm the existence and providence of God, then we should expect that refusals to make such an affirmation will rest on arguments, or to other considerations, which do not leave reason, including practical reason, intact and undistorted. I have already alluded to this matter in my remarks about Hume, Dawkins, and Dewey. And those reflections can be taken a little further.

41. Cf. Religious Freedom and the Constitution, 130, where the authors gratuitously postulate that a (hypothetical?) "mainstream Christian" majority consciously treat dissenters as "less than full members of our community" who lack "equal constitutional stature." 
The first condition for the acceptability of a philosophical position is that it be coherent not only with itself but also with the worth of critically reflecting on it, proposing it, arguing for it, and communicating it discursively to others. So, for example, positions about legal obligation must not only satisfy the test which H.L.A. Hart showed ${ }^{42}$ is failed by Holmesian Legal Realism, namely that it make real sense of the use of rules by judges, officials and other rule-followers-a use in which rules function not as predictions but rather as guides, directives, norms. Positions about legal obligation must also make sense of the willingness of such judges and others to treat positive legal rules in this way, in deliberations where at the time for decision the rules must either compete or cohere with the standing reasons for action that are supplied by moral requirements and other intelligible needs. Hart, as Nicola Lacey's biography shows, was tormented by what he knew to be the failure of his own legal philosophy to satisfy that condition. ${ }^{43}$ Blocking his way to a satisfactory account was his deep uncertainty about the status, as reasons, of moral and other deep practical principles and reasons for action; he could not see how they could be true-really reasons-without being somehow "part of the furniture of the universe," a metaphor he rightly regarded as discrediting what it purported to signify. And indeed the only ultimately satisfactory account of practical truth is one that first points to first practical principles such as I have exemplified by the principles directing us respectively to the good of truth and the good of friendship-and secondly understands these as principles that we do not select, fashion or invent, and that have their truth by anticipating the human fulfilment whose realization is possible through actions in conformity with these (and other like) principles; and that thirdly observes that though this anticipatory correspondence to fulfilment is different from the correspondence of true propositions to reality in non-practical knowledge, the two kinds of truth are nonetheless analogous since in both cases there is a correspondence of the human mind, and its objects, with the divine creative mind. ${ }^{44}$ That account of practical truth, though it is not free from mystery or challenge to the imagination, is coherent and sufficiently intelligible, and with it in place, we can range up and down the whole reach of practical thought, making good sense of the authority and obligatoriness of positive law and its "social fact sources." We can escape the fate of all those narrow legal positivisms shipwrecked by their aspiration to explain the legal "Ought" (which they rightly conceive as a kind of reason for action) by

42. Hart, The Concept of Law (Oxford: Clarendon Press, 1961), 1, 10-11.

43. Nicola Lacey, A Life of H.L.A. Hart: The Nightmare and the Noble Dream (Oxford and New York: Oxford University Press, 2004), 335-6.

44. See Grisez, Boyle, and Finnis, "Practical Principles, Moral Truth, and Ultimate Ends," 115-20; Finnis, Aquinas, 99-100. 
deriving it from some "Is"- a form of explanation which Plato and Aristotle discerned was fallacious long before Hume did, and far more steadily than Hume ever did.

Similarly, legal philosophy's account of agency and responsibility in contract formation, tort and criminal law must cohere with the facts of human freedom and responsibility to rational normativity which are instantiated, precisely as facts both experienced and at least partly understood, in one's critical questioning, reflecting and reasonably judging in this or any other area of philosophy. For philosophizing is an activity, and carrying it forward is subject at every moment to our freedom to back off, opt out, cheat, or persevere in fidelity to norms of rationality (attention to evidence, relevant questions, and argument, and so forth). And the mystery of this freedom of choice, so scandalous to materialists, is alleviated by two reflections: (1) that divine causality must be such that it could explain not only the causality that natural science seeks out and recounts but also those orders of reality-evidenced, like the order or reality studied by natural sciences, in every deliberate human act-orders whose intelligibility is not the object of natural sciences at all, the orders of logic, of practical reasoning towards choice and self-shaping action, and of mind's mastery over matter in technologies from speaking and ballet-dancing to moon-shots; and (2) that the creator's choice to bring about this universe rather than none or some other had a freedom which is surely the archetype of any choice of ours that is truly free.

Nietzsche's famous account of guilt and punishment, and conscience, in his On the Genealogy of Morals (1887) - a prime inspiration of today's postmodernisms - is a paradigm of the havoc wrought in a train of thought, a course of thinking, which is in some sense philosophical but truncated and turned against itself by (as Nietzsche is well aware) that refusal of natural theology which he gives the absurd but sinister name "the death of God." Suffice it to recall the last part of the Genealogy, in which he declares that willingness to seek and hold on to truth is itself a product of that sickness we call conscience. The truths that conscience is a sickness and that God, the only ground of truth's value, is nonexistent therefore put in question, render problematic, the will to truth, and the value of truth and being truthful: "the value of truth must for once, by way of experiment, be called into question." Nietzsche's phrase "by way of experiment" reveals the ultimately frivolous character of his thought, ${ }^{45}$ and the depth of the impasse to which his arbitrary

45. We do not have to decide about Nietzsche's character, or about what truth may be found in his work. Eric Voegelin, "Nietzsche, the Crisis and the War," Journal of Politics 6 (1944): 177-212, 185-6 presents him as a teller of truth about Europe's cultural suicide; elsewhere Voegelin shows him as a paradigm of the destruction wrought by atheism and the nihilism that 
assertions and denials have driven him. But he does not deny, indeed he here, at this juncture, admits that the "core" of conscience is, in fact, the will to truth and truthfulness. As he says, again, the "hard, severe, abstemious, heroic spirits ... these pale atheists, anti-Christians, immoralists, nihilists ... these men are far from free spirits: for they still believe in the truth!" And right here Nietzsche associates himself with the secretum of the highest grades of "that invincible order of the Assassins, that order of free spirits par excellence," (a sect of Shi'ite Muslims in Syria, Lebanon and northern Persia, whose operative killers called themselves fedayeen) - the secretum being, according to Nietzsche, that "nothing is true, everything is permitted." He calls this a "proposition" (true? false?) with "labyrinthine consequences" that will be worked out in "the great drama in a hundred acts which is reserved for Europe over the next two thousand years." $" 46$

In all this we have, of course, left reason and responsibility far behind, and are witnessing the performance of a kind of atheistical magician, a performance rationally inferior, by far, to the paradigms of religious thought. One of the evidences of its real impact in legal theoretical writings of recent years was Judge Posner's 1998 lectures at Harvard on law and morality. ${ }^{47}$ On the wider stage of the world, of course, such performances as Nietzsche's, such essays in decapitating reality by willfully refusing to admit reasonable questions and to pursue the self-critical, collaborative, discursive search for real causes wherever it leads, have had drastically real consequences. Eric Voegelin traced in detail ${ }^{48}$ the point at which the young Marx, some years before Nietzsche, issued to himself (as if to the world too) his decree against raising questions about ultimate origins, and gave himself over to the fantasy of self-creation which is at the root of his notion of revolutionary transformation of human nature and society, a notion for which so many paid so high a price with so little good fruit of any kind.

In short, decapitation of reality is dangerous to individuals and societies. Religion in principle repudiates what sound philosophy confirms is indeed such a decapitation. Treating religion as a private concern with the same public status as casual private sex insinuates a serious public untruth about the

is its rationally consistent accompaniment.

46. For citations and some further material, see Finnis, "Retribution: Punishment's Formative Aim," American Journal of Jurisprudence 44 (1999): 91-103, 92-94, esp. n. 17.

47. "The Problematics of Moral and Legal Theory," Harvard. Law Review 111 (1998): 1637 (see the opening quotation).

48. "Science, Politics, and Gnosticism" [1958], in The Collected Works of Eric Voegelin, vol. 5, Modernity Without Restraint, ed. Manfred Henningsen (Columbia, MO: University of Missouri Press, 2000), 262-5, 268-71, 274, 279-80, 284-6 
reality in which political communities and their law have their place. ${ }^{49}$ The political community's public duty to respect, that is, to leave uncoerced, the conscientious religious beliefs and acts of everyone, even beliefs that include much that is false and acts that are accordingly ill-justified, is a duty grounded in a serious moral (not legal) duty of each individual —one's duty: to seek the truth about reality's most fundamental shape and, having raised and pursued that question, to shape one's life in line with what one judges one has discovered about such matters, a duty which is only fulfilled if it is pursued with an authenticity that would be prejudiced, corrupted and even nullified by coercion and psychological pressure. ${ }^{50}$

\section{VI}

Before I conclude with a secondary reason or pair of reasons for giving free exercise of religion constitutional protection, I should say something on the appropriate form and measure of that protection. Forbidding or invalidating the prohibition of free exercise of religion is probably not as satisfactory as declaring a right such as that articulated in Art. 25 of the Constitution of the Republic of India, brought into effect in January 1950 after more than two years of lucid and intelligent public debate in a constitutional convention:

\section{Right to Freedom of Religion}

25. (1) Subject to public order, morality and health and to the other provisions of this Part, all persons are equally entitled to freedom of conscience and the right freely to profess, practise and propagate religion.

49. This damaging insinuation is analogous to (though significantly distinct from) the damaging insinuation (teaching) portrayed by J. Budziszewski, What We Can't Not Know (Dallas: Spence, 2004), 162: “A good many parents decline to give their children any religious instruction, saying that they think it is better to "let them make up their own minds." But declining to teach [religion] is itself a way of teaching ... a very definite creed with eight articles: (1) It is not important for children to know anything about God. (2) The questions which children naturally ask about Him require no answers. (3) Parents know nothing about Him worth passing on. (4) To think about Him adequately, no preparation is needed. (5) What adults think about Him makes no difference. (6) By implication, He does not make any difference either; God is not to be treated as God. (7) If anything is to be treated as God, it will have to be something other than Him. (8) This is the true creed, and all other creeds are false.... [A person thus] raised to "make up his own mind" ... [will have] the habit of not taking important things seriously, and the habit of considering the way things really are as less important than what he thinks of them at the moment."

50. That is the fundamental argument in Second Vatican Council, Declaration on Religious Liberty, 1965 (Dignitatis Humanae). 
Later in the same year, the European Convention on Fundamental Rights and Freedoms articulated:
Article 9-Freedom of thought, conscience and religion
1. Everyone has the right to freedom of thought, conscience and religion; this right includes freedom to change his religion or belief and freedom, either alone or in community with others and in public or private, to manifest his religion or belief, in worship, teaching, practice and observance.

The European formulation has some advantages. It suggests one of the reasons why it is appropriate not to be content with declaring a right to freedom of thought and conscience. Much more clearly than "thought" and "conscience," the term "religion" connotes activities which extend from the individual to the associative and social, and from the private to the public, even when the Indian Constitution's reference to propagation is omitted. The European formulation also makes explicit the freedom to change one's religion, something which you here in Minnesota know is of increasing importance; and the Second Vatican Council's articulation of the freedom ${ }^{51}$ makes helpfully explicit that, morally if not constitutionally, the right is to be "immune from coercion whether by individuals or social groups and by every kind of human power." 52

51. This is essentially a right to be free from coercion when one is exercising one's conscience in forming, holding or giving effect in action to one's beliefs "in matters religious" (in re religiosa). This freedom from coercion was often described by the drafting committee as an immunity. And though it is not an immunity in the sense stipulated by Hohfeld in his analysis of jural relations, there is no objection to using "immunity" as a synonym for a claimright not to be interfered with or coerced. The "religious liberty" is nothing more, nor less, than a claim-right not to be coerced in performing religious acts, individual or corporate within due limits.

It follows that the fundamental topic of Dignitatis Humanae is in substance not a libertyright (stricto sensu) but duty - the duty of state government and law, and of other groups and individuals in civil society, not to coerce anyone's religious acts unless they threaten the rights of others, public peace, or public morality. The right of religious liberty-freedom from coercion -that is the subject-matter of $D H$ is nothing other the correlative of that duty, i.e., it is nothing other than that duty considered from the point of view of the beneficiary of (the performance of) that duty. For analysis of the Declaration and its drafters' intentions on this issue, see Finnis, "Religion and State: Some Main Issues and Sources," American Journal of Jurisprudence 51 (2006): 107-30 at 120-22.

52. Dignitatis Humanae 2: "This Vatican Council declares that human persons have the right to religious freedom. This kind of freedom consists in this: that all human beings ought to be immune from coercion whether by individuals or social groups and by every kind of human power, so that in religious matters no-one is compelled to act against his or her conscience or impeded from acting according to his or her conscience, whether acting publicly or privately, alone or in association with others, within due limits." The Latin is: "Haec 
The modern constitutional and ecclesiastical documents all try to specify the boundaries of the right or freedom. The European Convention, for example, says (Art. 25(2)) the "Freedom to manifest one's religion or beliefs shall be subject only to such limitations as are prescribed by law and are necessary in a democratic society in the interests of public safety, for the protection of public order, health or morals, or for the protection of the rights and freedoms of others." " In practice, despite the use here of the Convention's stock phrase "necessary in a democratic society," this principle of limitation works much more like Employment Division v. Smith than like the earlier U.S. principle in Sherbert v. Verner (1963), ${ }^{54}$ which permitted limitations on free exercise of religion only when required by some compelling state interest. So we can ask about both Smith and Art. 25(2): Do they give sufficient constitutional protection? Obviously, much could be said, and I will skip to the bottom line. There can be problems that are not really about boundaries but about abuses, moral errors by legislators or judges that can scarcely be protected against by sound constitutional provisions. The application of general and (in intent) religiously neutral laws against discrimination can be unjust and a grave imposition on religious or religiously organized and inspired enterprises. Such is the case with laws prohibiting discrimination against persons who make no secret of their engaging in samesex sex acts but wish to be employed as teachers in Catholic or Evangelical schools or to make use of Catholic or Evangelical facilities such as adoption

Vaticana Synodus declarat personam humanam ius habere ad libertatem religiosam. Huiusmodi libertas in eo consistit, quod omnes homines debent immunes esse a coercitione ex parte sive singulorum sive coetuum socialium et cuiusvis potestatis humanae, et ita quidem ut in re religiosa neque aliquis cogatur ad agendum contra suam conscientiam neque impediatur, quominus iuxta suam conscientiam agat privatim et publice, vel solus vel aliis consociatus, intra debitos limites." The scandalously inadequate translation currently on the Vatican website reads: "This Vatican Council declares that the human person has a right to religious freedom. This freedom means that no one is to be forced to act in a manner contrary to his own beliefs, whether privately or publicly, whether alone or in association with others, within due limits."

53. The Indian limiting provision is built into the text of art. 25(1), and is amplified by art. 25(2): "(2) Nothing in this article shall affect the operation of any existing law or prevent the State from making any law-(a) regulating or restricting any economic, financial, political or other secular activity which may be associated with religious practice; $(b)$ providing for social welfare and reform or the throwing open of Hindu religious institutions of a public character to all classes and sections of Hindus."

Dignitatis Humanae 7 says the right can be made subject to legal limitations arising out of "the need for an effective safeguard of the rights of all citizens and for the peaceful settlement of conflicts of rights, also out of the need for an adequate care of genuine public peace, which comes about when people live together in good order and in true justice, and finally out of the need for a proper guardianship of public morality."

54. 374 U.S. 398. 
agencies, church halls, and so forth. The mentality which regards same-sex marriage as conceivable, let alone desirable or reasonable, involves a truly radical break with human experience and reason. The consequent unjust impositions on religious or religiously motivated activities and associations are probably best resisted by pointing, not to religious liberty, but to the way these impositions infringe associational freedom and parental rights, while pointing in any case to their manifold wrong-headedness about sex and marriage, to their abuses of children's innocence, and to their recklessness about the common good and the nation's future. In short, I am rather disinclined to protest, as Congress has, against the principle in Smith; its requirement that any law limiting free exercise be neutral, given vivid effect in the Santeria animal sacrifice case, ${ }^{55}$ should give religion the constitutional protection it deserves and in some eras may need.

\section{VII}

Two secondary, rather pragmatic reasons to judge religion deserving of constitutional protection come into view when we raise a final question. What if a religion rejects on principle the right to religious freedom as defined, for example, in the ECHR's reference to freedom to change one's religion, and rejects also other fundamental elements of our constitutional order? After all, it's only five or six years since the eighteen judges of the European Court of Human Rights held unanimously, in Refah Partisi (No.2) v Turkey, that:

...the Court considers that sharia, which faithfully reflects the dogmas and divine rules laid down by religion, is stable and invariable. Principles such as pluralism in the political sphere or the constant evolution of public freedoms have no place in it.... a regime based on sharia ... clearly diverges from Convention values, particularly with regard to its criminal law and criminal procedure, its rules on the legal status of women and the way it intervenes in all spheres of private and public life in accordance with religious precepts. .[A] political party whose actions seem to be aimed at introducing sharia ... can hardly be regarded as an association complying with the democratic ideal that underlies the whole of the Convention. ${ }^{56}$

On that basis the ECtHR upheld the Turkish Supreme Court's dissolution of Turkey's elected Government and of the country's main party, on the grounds

55. Church of the Lukumi Babalu Aye, Inc. v City of Hialeah, 508 U.S. 520 (1993).

56. Refah Partisi (No. 2) v. Turkey 37 European Human Rights Reports 1 (2003), at sec. 123 (emphasis added), Grand Chamber, upholding and adopting the language of the Third Section of the ECtHR in Refah Partisi (No. 1) v Turkey 35 European Human Rights Reports 3 (2002). 
that the Government in which that party was dominant was, or might well be, preparing to introduce sharia either as law applicable to all or as part of a scheme in which every citizen would be subjected to the law of his or her own religion respectively.

Contemporary American constitutionalists are deeply suspicious of this sort of "militant democracy"-pre-emptive defense of democracy-even when practiced, as here, by a court (initially the supreme court in Turkey) They will tend to find it even more questionable when it asks you to focus steadily on the possibility that a particular religion - the private faith of fellow citizens or of hard-up immigrants - might be different from all other religions in its core beliefs about the Constitution, and about the legitimacy of long-term deception and intimidation in the cause of overthrowing it or, much more immediately, in the cause of rendering certain constitutional guarantees, and related moral rights, inapplicable within the religion's zone of dominance. For I should not conceal the fact that it was part of Turkey's case before the ECtHR that "In order to attain its ultimate goal of replacing the existing legal order with sharia, political Islam use[s] the method known as "takiyye", which consist[s] in hiding its beliefs until it ha[s] attained that goal." The Court did not make any explicit finding about Islamic takiyye (a practice which had not, it seems, been denied by the applicant members of the dissolved government and party), but it did observe more broadly that political parties and movements may conceal their aims and profess their adherence to democracy and the rule of law until it is too late to prevent them overthrowing both. ${ }^{57}$ Still, for present purposes we do not really need to speculate about the possible secret intentions of particular members of the Islamic religion. We can study the open public documents and declarations of states publicly holding themselves out, and cooperating with each other, precisely as Islamic states, such as the Cairo Declaration on Human Rights in Islam, adopted by the governments of 45 states in August $1990^{58}$ as superior to the Universal Declaration of Human Rights adopted by the General Assembly of the United Nations in 1948. This 1990 Islamic Declaration's article on religious freedom reads as follows: “(10) Islam is the religion of true unspoiled nature. It is prohibited to exercise any form of pressure on man or to exploit his poverty or ignorance in order to force him to change his religion to another religion or to atheism." That's all. But articles 24 and 25 add, for good measure: "(24) All the rights and freedoms stipulated in this Declaration are subject to the Islamic Shari'ah.

57. Refah (No. I) at secs. 48 and 80; Refah (No.2), at sec. 101.

58. U.N. GAOR, World Conference on Human Rights., 4th Sess., Agenda Item 5, U.N. Doc. A/CONF.157/PC/62/Add.18(1993). The declaration is by the Organization of the Islamic Conference, to which now (2009) belong 57 states; approval of the document was by the organ of the Conference which meets annually, the Islamic Conference of Foreign Ministers. 
(25) The Islamic Shari'ah is the only source of reference for the explanation or clarification of any of the articles of this Declaration."

These realities put a question-mark over more than one part of the orthodoxy of American free exercise doctrine. They raise a doubt about the part that says the law and the Court must make no investigation of a religion's doctrines, and over the part, treated as axiomatic by justices of every shade of opinion, that forbids any discrimination between religions. What if the "theological propositions of a religion" include political teachings "wholly at odds with premises of our liberal democracy" or, to speak like the ECtHR, "with the democratic ideal that underlies the whole of the [Constitution]" or, to speak I think more suitably, with the Constitution and other principles that we have taken as foundational for our law? Is it unconstitutional to discriminate between religions at the borders? Would doing so amount to a wrongful disparagement of adherents of the religion who are already citizens? Would it wrongfully impinge upon their free exercise of religion? Or violate the human right to religious liberty of those who would be kept out of the country in the interests of the nation's public order?

In thinking about the last question, we come across one of the secondary reasons for constitutionally acknowledging religious liberty: that that guarantee fittingly accompanies the appropriate principle of distinction between religion and state, the principle which the Constitution witnesses to, perhaps, by its exclusion of religious tests and prohibition of Congressional establishment of religion. ${ }^{59}$ The distinction is, of course, of wide and fundamental importance. It is theme enough for another lecture. The only implication of it that I wish to touch on is its relevance to thinking about control of immigration. In that precise connection we can see it at work in one of the present Pope's first statements:

Single believers are called to open their arms and their hearts to every person, from whatever nation they come, allowing the Authorities responsible for public life to enforce the relevant laws held to be appropriate for a healthy coexistence. $^{60}$

59. The principle appears in another way in the second reason given by Dignitatis Humanae for religious liberty: " "The religious acts whereby men, in private and in public and out of a sense of personal conviction, direct their lives to God transcend by their very nature the order of terrestrial and temporal affairs. Government therefore ought indeed to take account of the religious life of the citizenry and show it favor, since the function of government is to make provision for the common welfare. However, it would clearly transgress the limits set to its power, were it to presume to command or inhibit acts that are religious [actus religiosos dirigere vel impedire]." (DH 3, emphasis added)

60. Benedict XVI, Address to the Pontifical Council for Pastoral Care of Migrants and Itinerant People, 15 May 2006: http://www.vatican.va/holy_father/benedict_xvi/speeches/ 
Within a universal religious community such as the Pope's there is no distinction between citizen and foreigner. But, as his words make plain, it does not follow that such a distinction may not have decisive relevance to the common good, and indeed the public order, of political communities.

So a nation state, if not this one, any time soon, then one or more of the European states more immediately affected, might judge it reasonable to limit or forbid further immigration by persons unwilling to credibly renounce their religion's core theologico-political and numbers-dependent drive to impose political and legal domination. ${ }^{61}$ But then - and here is the other secondary reason I want to mention for constitutionally guaranteeing free exercise-it would be all the more important, you may agree, firmly to protect the right-a qualified right, of course ${ }^{62}$ - of citizens to practice that religion (as well as the right, repudiated by their religion's law or doctrine, to renounce it).

2006/may/documents/hf_ben-xvi_spe_20060515_pc-migrants_en.html. Nothing in the particularly vague paragraph on international migration in the encyclical Caritas in Veritate (29 June 2009), sec. 62, qualifies this.

61. Because numbers-critical masses-matter, times change. A legislature looking forward from now, or fairly soon, might responsibly decide that the only likely medium-term constructive alternative to forbidding immigration by persons unwilling to make that renunciation will foreseeably prove to be the state-promoted introduction - as is beginning to be ventured in France, Germany and the UK-of an emasculated version of that highly distinctive religion, supervised by state instrumentalities responsible for selecting its teachers and preachers in the hope of watering down its inbuilt focus on domination, violence and submission, its division of the world into the world of submission and the world of war, its public and private subjection of women, and other features that (so the legislature might judge) make it at best inassimilable and at worst a clear and mounting danger to the public good. If the latter alternative (a State-sponsored form of that religion) is to be judged permanently unavailable here, because a plain "establishment of religion," still the resort to it by centrist European governments may go some way towards (a) showing a compelling state interest in not treating that religion and its followers in just the same way as others, and thus (b) surmounting the bar raised by the beguiling but curious doctrine of the Supreme Court that discrimination against one religion is not only unfair but also an establishment of all the others (and of irreligion?).

62. See n. 53 above. 